\title{
PEMBELAJARAN KOOPERATIF DENGAN PERMAINAN PUZZLE DAPAT MENINGKATKAN AKTIVITAS DAN HASIL BELAJAR IPA SISWA DI SMP NEGERI 4 PRINGSEWU
}

\author{
LENI OKTARINI \\ SMP Negeri 4 Pringsewu \\ e-mail: oleni0522@gmail.com
}

\begin{abstract}
ABSTRAK
Penelitian ini berbentuk Penelitian tindakan kelas (PTK) bertujuan untuk mendiskripsikan pembelajaran kooperatif dengan permainan puzzle dapat meningkatkan aktivitas belajar dan hasil belajar siswa kelas VII SMP Negeri 4 Pringsewu Provinsi Lampung di Tahun Pelajaran 2018/2019, pada Pelajaran IPA materi organisasi mahluk hidup. Penelitian tindakan kelas ini terdiri atas 3 siklus. Setiap siklusnya terdiri dari tahapan perencanaan, pelaksanaan tindakan, observasi dan refleksi. Penelitian ini juga bersifat kolaboratif dengan subyek penelitian adalah siswa kelas 7c yang berjumlah 32 siswa. Teknik pengumpulan data dilakukan dengan cara observasi, penyebaran angket, tes serta dokumentasi. Teknik analisis data dilakukan dengan mengunakan analisis deskriptif kualitatif. Hasil penelitian menunjukan bahwa Penerapan pembelajaran kooperatif dengan permainan puzzle pada materi organisasi mahluk hidup pada siklus 1 ketuntasan belajar klasikal siswa sebesar 40,28\% dengan nilai rata-rata 64. Pada siklus II, ketuntasan belajar klasikal siswa sebesar $71.87 \%$ dengan nilai rata-rata 71 dan pada siklus 3 diperoleh ketuntsan klasikal sebesar 78,86\% dengan rata-rata 75 . Untuk aktivitas belajar siswa diperoleh Aktivitas siswa dalam pembelajaran dengan model pembelajaran kooperatif dengan permainan puzzle pada siklus 1 dalam kategori cukup baik. Pada siklus 2 diperoleh skor aktivitas siswa yang meningkat baik dan pada siklus 3 diperoleh data aktivitas siswa yang lebih baik lagi dari siklus 2. Model pembelajaran kooperatif dengan permainan puzzle lebih efektif untuk meningkatkan aktivitas dan hasil belajar siswa kelas VII SMP Negeri 4 Pringsewu pada mata pelajaran IPA Terpadu materi organisasi mahluk hidup I Tahun pelajaran 2018/2019.
\end{abstract}

Kata Kunci: Aktivitas, Hasil Belajar IPA, Pembelajaran kooperatif permainan puzzle

\section{PENDAHULUAN}

Hasil belajar yang mencapai kreteria ketuntasan minimal adalah salah satu dari banyak tujuan dari proses pembelajaran yang dilakukan di sekolah. Guru sebagai fasilitator di kelas harus mampu menciptakan beraneka ragam pendekatan untuk mencapai hasil belajar yang lebih baik dari hanya sekedar hasil belajar yang mencapai kreteria ketuntasan minimal. Dalam mengembangkan pendekatan yang tepat dalam proses pembelajaran, seorang guru harus mampu memilih pendekatan pembelajaran yang sesuai dengan karaktristik siswa, sarana prasarana sekolah, dan materi yang akan diajarkan

Berdasarkan pengalaman di kelas sebagai guru Ilmu Pengetahuan Alam kelas VII banyak menemukan kendala-kendala yang sangat tinggi pada materi Organisasi mahluk hidup Kendala yang dihadapi diantaranya rendahnya aktivitas belajar siswa di kelas sebelum belajar siswa hingga proses pembelajaran dan tingginya kecendrungan siswa untuk bermain dan mengobrol topik di luar materi yang akan dipelajari.

Hasil belajar mata pelajaran IPA pada semester genap yang lalu, dari jumlah siswa kelas VII yaitu 32 orang siswa, dengan standar KKM 70 hanya terdapat 9 orang siswa (28\%) yang mencapai nilai Kreteria Ketuntasan minimal, sedangkan terdapat 21 orang siswa (72\%) yang nilainya masih dibawah Kreteria Ketuntasan minimal. Hal ini menandakan bahwa hasil belajar siswa pada mata pelajaran IPA pada konsep organisasi mahluk hidup masih rendah. Selain rendahnya nilai yang diperoleh siswa pada penilaian harian materi organisasi mahluk hidup juga diikuti rendahnya aktivitas belajar siswa.

Berdasarkan dua permasalahan di atas perlu adanya strategi dan pendekatan baru dalam pembelajaran untuk meningkatkan aktivitas dan hasil belajar siswa dengan dasar karaktristik 
siswa di kelas yang suka dengan bermain. Pada penelitian ini, peneliti menggunakan model pembelajaran kooperatif dengan permainan puzzle. Model pembelajaran kooperatif dengan permainan puzzel, dapat merangsang keaktifan siswa. Siswa akan memecahkan materi sendiri, kemudian mengajarkan kepada teman-temanya dengan didukung keinginan membaca dan mendengar dengan kuat dalam menyelesaian permainan puzzle dengan tema materi pelajaran IPA.

IPA menurut Trianto (2010: 136), merupakan suatu kumpulan pengetahuan yang tersususn secara sistematis yang dalam penggunaannya secara umum terbatas pada gejalagejala alam. .Ruang Lingkup bahan kajian IPA untuk SMP dalam BSNP (2006:162) meliputi aspek-aspek berikut, (1) makhluk hidup dan proses kehidupan, yaitu manusia, hewan, tumbuhan dan interaksinya dengan lingkungan, serta kesehatan. (2) benda/materi, sifat-sifat dan kegunaannya meliputi: cair, padat dan gas. (3) energi dan perubahannya meliputi: gaya, bunyi, panas, magnet, listrik, cahaya dan pesawat sederhana. (4) bumi dan alam semesta meliputi: tanah, bumi, tata surya, dan benda-benda langit lainnya

Dengan sistem pembelajaran pada model kooperatif dengan permaianan puzzle diharapkan aktivitas dan hasil belajar siswa akan meningkat. Oleh sebab itu perlu diadakannya penelitian untuk mengetahui efektifias model pembelajaran kooperatif dengan permainan puzzle dalam meningkatkan aktivitas dan hasil belajar siswa pada mata pelajaran IPA kelas VII pada materi organisasi mahluk hidup di SMP Negeri 4 Pringsewu semester genap tahun pelajaran 2018/2019

Menurut Paul D. Dierich dalam (Hamalik, 2007:172) aktivitas belajar siswa dapat digolongkan sebagai berikut: 1)kegiatan visual 2) kegitan lisan 3) kegiatan mendengarkan 4) kegiatan menulis 5)kegiatan menggambar 6) kegiatan metric 7) kegiatan mental 8) kegiatan emosional.. dan diperkuat dengan pendapat Hamalik sendiri, (2010: 28), yang mengatakan bahwa aktivitas belajar merupakan segala bentuk interaksi yang dilakukan siswa dan guru dalam rangka mencapai tujuan pembelajaran. Pada aktivitas yang dilakukan oleh siswa dalam pembelajaran, mereka belajar sambil bekerja. Melalui kerja sama tersebut, siswa mendapatkan pengetahuan, pemahaman, dan aspek-aspek tingkah laku lainnya. Adanya perubahan paradigma pendidikan saat ini menuntut dilakukannya perubahan proses pembelajaran di dalam kelas. Peran guru saat ini diarahkan untuk menjadi fasilitator yang dapat membantu siswa dalam belajar, bukan sekedar menyampaikan materi saja. Guru harus mampu melibatkan siswa dalam kegiatan pembelajara secara optimal

Hasil belajar menurut Dimyati dan Mudjiono (2006:45) hasil belajar adalah hasil yang dicapai dalam bentuk angka-angka atau skor setelah diberikan tes hasil belajar pada setiap akhir pembelajaran. Nilai yang diperoleh siswa menjadi acuan untuk melihat penguasaan siswa dalam menerima materi pelajaran, sedangkan menurut Mulyasa, (2008:23) hasil belajar merupakan prestasi belajar siswa secara keseluruhan yang menjadi indikator kompetensi dan derajat perubahan prilaku yang bersangkutan. Kompetensi yang harus dikuasai siswa perlu dinyatakan sedemikian rupa agar dapat dinilai sebagai wujud hasil belajar siswa yang mengacu pada pengalaman langsung.

Dalam rangka mengotimalkan terwujudnya aktivitas belajar dan hasil belajar siswa maka diperlukan terobosan pembelajaran yang menyenangkan bagi siswa sesuai dengan karaktistik siswa di kelasnya. Oleh sebab itu berdasarkan alasan dan faktor-faktor yang mendukung untuk mewujudkan optimalisasi aktivitas belajar dan hasil belajar maka yang menjadi alternatif dalam penilitian kali ini adalah proses pembelajaran kooperatif dengan permainan puzzle.

Pembelajaran kooperatif Menurut Suprijono (2010:54) model pembelajaran kooperatif adalah konsep yang lebih luas meliputi semua jenis kerja kelompok termasuk bentuk-bentuk yang dipimpin oleh guru atau diarahkan oleh guru. Sedangkan menurut Slavin dalam Isjoni (2007:15) pembelajaran kooperatif adalah suatu model pembelajaran dimana sistem belajar dan bekerja kelompok- kelompok kecil berjumlah 4-6 orang secara kolaboratif sehingga dapat merangsang peserta didik lebih bergairah dalam belajar. 
Berdasarkan pendapat para ahli di atas, maka disimpulkan bahwa pembelajaran kooperatif adalah cara belajar dalam bentuk kelompok- kelompok kecil yang saling bekerjasama dan diarahkan oleh guru untuk mencapai tujuan pembelajaran yang diharapkan

Agar aktivitas belajar siswa terlihat dalam pembelajaran kooperatif maka permainan puzzle menjadi alternatif yang perlu dipilih mengingat kreatifitas siswa yang masih suka dengan bermain. Puzzle merupaka sebuah permainan menyusun potongan gambar-potongan gambar untuk dijadikan gambar yang utuh yang sebelumnya diacak terlebih dahulu. Menurut www.schoolpouright/puzzel, " puzzle berasal dari bahasa inggris yang artinya tebak tebakan dan ditemukan oleh John spilbury". Dan puzzle ini pertamakali dipakai dalam pembelajaran geografi berkaitan dengan peta. Permaianan puzzle ternyata banyak manfaatnya, menurut www.schoolpouright.puzzel permainan puzzle memeliki manfaat dianataranya, memperkuat ingatan jangka pendek, mencegah penyakit deimensia, melatih anak memecahkan masalah, melatih koordinasi mata dengan tangan, melatih ketrampilan special otak, melatih ketrampilan kognitif dan melatih kesabaran.

Menurut Nisak (2011: 111), permainan inim mempunyai teknis sebagai berikut: 1) Guru menerangkan aturan permainan. Permainan ini dilakukan secara berkelompok. 2) Sebelum permainan dimulai dilakukan pembagian kelompok. Satu kelompok terdiri dari 5 anggota kelompok. 3) Siapkan puzzle dalam amplop untuk masing-masing kelompok. 4) Permainan inidibatasi dengan waktu 15 menit. 5) Masing-masing Penggunaan Media Puzzle untuk kelompok berdiri melingkari meja dan didekat amplop puzzle yang telah dibagikan. 6) Masingmasing kelompok harus mengerjakan secara berkelompok, tidak boleh ada yang mengerjakan sendirian. 7) Guru memberikan umpan balik berupa pertanyaan-pertanyaantentang gambar yang telah mereka rangkai.

Berdasarkan beberapa manfaat di atas maka permainan puzzle bisa digunakan dalam proses pembelajaran di kelas untuk mata pelajaran IPA untuk memperlancar proses pembelajaran kooperatif. Saat ini guru dimudahkan dengan aplikasi permainan puzzle dengan beraneka ragam bentuk gambar yang bisa dirangkai oleh siswa. Dugaan sementara dalam penelitian ini adalah pembelajaran kooperatif dengan permainan puzzle dapat meningkatkan aktivitas belajar dan hasil belajar siswa.

\section{METODE PENELITIAN}

Penelitian ini dilakuksanakan dalam bentuk penilitian tindakan kelas (PTK) dengan tiga siklus tindakan. Penelitian ini menggambarkan suatu model pembelajaran diterapkan dan bagaimana hasil yang diinginkan dapat tercapai, dan pada penelitian ini peneliti menggunakan bentuk penelitian tindakan kolaboratif, dimana peneliti bekerja sama dengan rekan sejawat. Penelitian ini mengacu pada perbaikan pembelajaran yang berkesinambungan dan menyenangkan. Model penelitian tindakan kelas yang digunakan pada penelitian ini adalah model Spiral dalam bukunya Arikunto,(2006: 92-93) menyatakan bahwa pelaksanaan PTK diawali dengan melakukan perencanaan kemudian melaksanakan tindakan, pengamatan atau obersevasi dan refleksi.

Siklus 1 terdiri atas empat tahapan yaitu (1) Perencanaan, pada tahap ini berupa penyusunan rancangan tindakan, yang meliputi kegiatan berikut: (a) Mempersiapkan rencana pelaksanaan pembelajaran, (b) mempersiapkan puzzle sub materi sel, (c) mempersiapkan lembar observasi untuk guru dan siswa, (d) mempersiapkan pembentukan kelompok kecil yang terdiri dari 4 orang (e) mempersiapkan alat evaluasi, tahap (2) Pelaksanaan Tindakan, pada tahap ini, rancangan strategi dan skenario penerapan pembelajaran akan diterapkan meliputi kegiatan sebagai berikut:(a) Guru menyampaikan informasi tentang tujuan pembelajaran pada materi system organisasi mahluk hidup khususnya sub materi sel, (b) Guru membagikan lembar materi bentuk sel hewan dan tumbuhan dengan fungsinya desertai setiap peserta didik memiliki buku paket IPA revisi 2017, (c) Guru memberikan informasi tentang langkah-langkah permainan puzzle dalam pembelajaran kooperatif kali ini, (d) Guru menerapkan langkahlangkah pembelajaran kooperatif dengan permainan puzzle sebagai berikut, (1) guru 


\section{SCIENCE : Jurnal Inovasi Pendidikan Matematika dan IPA Vol. 1 No. 2 Agustus 2021 e-ISSN : 2797-1031 | p-ISSN : 2797-0744}

membimbing pembentukan kelompok siswa (delapan kelompok) masing kelompok berjumlah 4 peserta didik heterogen, (2) guru memberikan contoh cara pemasangan pazzle yg sederhana, (3) guru membagikan permainan puzzle pada setiap kelompok, (4) guru meminta setiap siswa memasang puzzle tersebut selama 15 menit, sebanyak dua sesi, (5) guru mendampingi siswa dalam presentasi hasil pemasangan puzzlenya serta mendampingi jalannya diskusi, (6) guru dan siswa bersama-sama menyimpulkan hasil pembelajaran materi sel, (7) Guru mengadakan test akhir siklus 1. Pada tahap (3) Melakukan pengamatan atau observasi hasil tes maupun lembar observasi Pengumpulan data dilakukan dengan menggunakan dua teknik pengumpulan data, yaitu tes dan non tes. Instrumennya antara lain sebagai berikut: (a) Tes tertulis dilakukan untuk mengetahui sejauh mana kemampuan kognitif peserta didik. Pada penelitian ini, tes tertulis digunakan untuk mengukur hasil belajar siswa pada pembelajaran IPA menggunakan model pembelajaran kooperatif dengan permaianan puzzle. (b) Observasi adalah pengamatan dan pencatatan secara sistematik terhadap unsur-unsur yang tampak dalam sebuah penelitan. Pada penelitian ini, observasi dilakukan untuk mengamati aktivitas siswa pada pembelajaran IPA menggunakan model pembelajaran kooperatif dengan permainan puzzle serta untuk mengobservasi kinerja gurudata sedangkan tahap (4) Refleksi siklus 1 untuk perbaikan tindakan di siklus 2.

Siklus 2, tahapan yang dilakukan sama dengan siklus 1, ada empat tahapan yaitu, tahap (1) Perencanaan, Tahap ini berupa penyusunan rancangan tindakan, yang meliputi kegiatan berikut, (a) mempersiapkan Rencana Pelaksanaan Pembelajaran, (b) mempersiapkan puzzle sub materi Jaringan dan Organ, (c) mempersiapkan lembar observasi untuk guru dan siswa, (d) mempersiapkan pembentukan kelompok kecil yang terdiri dari 4 orang, dan (e) mempersiapkan alat evaluasi. Tahap (2) Pelaksanaan tindakan, Pada tahap ini, rancangan strategi dan skenario penerapan pembelajaran akan diterapkan meliputi kegiatan sebagai berikut, (a) guru menyampaikan informasi tentang tujuan pembelajaran pada materi system organisasi mahluk hidup khususnya sub materi Jaringan dan organ, (b) guru membagikan lembar materi bentuk sel hewan dan tumbuhan dengan fungsinya desertai setiap peserta didik memiliki buku paket IPA revisi 2017, (c) guru memberikan informasi tentang langkah-langkah permainan puzzle dalam pembelajaran kooperatif kali ini, (d) guru menerapkan langkah-langkah pembelajaran kooperatif dengan permainan puzzle sebagai berikut, (1) guru membimbing pembentukan kelompok siswa (delapan kelompok)masing kelompok berjumlah 4 peserta didik heterogen, (b) guru memberikan contoh cara pemasangan pazzle yg sederhana, (c) guru membagikan permainan puzzle pada setiap kelompok, (d) guru meminta setiap siswa memasang puzzle tersebut sebanyak dua gambar dalam dalam waktu dua menit (4 peserta didik dikali 2 menit sama dengan delapan menit sisa waktu 2 menit peserta didik mengkoreksi $=10$ menit puzzle sudah terangkai), (e) guru membagikan puzzle materi sel sebanyak 3 gambar untuk setiap siswa dan siswa diharuskan menyelesaikan gambar tersebut selama 15 menit, sebanyak dua sesi, (f) guru mendampingi siswa dalam presentasi hasil pemasangan puzzlenya serta mendampingi jalannya diskusi, (f) guru dan siswa bersama-sama menyimpulkan hasil pembelajaran materi Jaringan dan organ dan (g) guru mengadakan test akhir siklus 2. Tahap (3) Pengamatan atau Observasi Pengumpulan data dilakukan dengan menggunakan dua teknik pengumpulan data, yaitu tes dan non tes. Instrumennya antara lain sebagai berikut: (a) Tes tertulis dilakukan untuk mengetahui sejauh mana kemampuan kognitif peserta didik. Pada penelitian ini, tes tertulis digunakan untuk mengukur hasil belajar siswa pada pembelajaran IPA menggunakan model pembelajaran kooperatif dengan permaianan puzzle. (b) Observasi adalah pengamatan dan pencatatan secara sistematik terhadap unsur-unsur yang tampak dalam sebuah penelitan. Pada penelitian ini, observasi dilakukan untuk mengamati aktivitas siswa pada pembelajaran IPA menggunakan model pembelajaran kooperatif dengan permainan puzzle serta untuk mengobservasi kinerja guru. Tahap 4 merupakan refleksi siklus dua untuk perbaikan di siklus 3. 
Siklus 3 tahapannya sama dengan siklus 2 yang membedakan hanya di materi yang disampaikan yaitu tentang sistem organ dan organisme yang masih menjadi bagian dari materi organisasi mahluk hidup.

\section{HASIL DAN PEMBAHASAN}

Penelitian ini dilaksanakan dalam tiga siklus, dan setiap siklus untuk satu pertemuan. Pada siklus 1 guru sudah menggunakan strategi pembelajaran kooperatif dengan permainan puzzle dengan cukup baik walaupun masih ada kendala-kendala yang dihadapi siswa karena permainan puzzle merupakan permain yang baru dipakai siswa kelas VII. Pada siklus 1 pembelajaran kooperatif dengan permainan puzzle dalam pembelajaran kooperatif diperoleh nilai rata-rata siswa 64 dengan persentase ketuntasan belajar secara klasikal adalah 40,62\%. Perbandingan hasil belajar sebelum dan sesudah siklus 1,2, dan 3 dapat dilihat sebagai berikut.

Tabel 1 Rekap Hasil Belajar Siswa Kelas VII SMP Negeri 4 Pringsewu

\begin{tabular}{|l|c|c|c|c|}
\hline \multicolumn{1}{|c|}{ Keterangan } & $\begin{array}{c}\text { Sebelum } \\
\text { Tindakan }\end{array}$ & Siklus 1 & Siklus 2 & Siklus 3 \\
\hline Nilai tertinggi & 80 & 90 & 90 & 100 \\
\hline Nilai terendah & 30 & 30 & 40 & 50 \\
\hline Rata-rata nilai siswa & 55 & 64 & 71 & 75 \\
\hline Ketuntasan klasikal & $28,13 \%$ & $40,62 \%$ & $71,87 \%$ & $78,12 \%$ \\
\hline
\end{tabular}

Sesuai tabel tersebut di atas, terlihat adanya kenaikan cukup signifikan dalam hal ketuntasan belajar klasikal siswa, yaitu dari sebelum dilakukan tindakan sebesar 28,13\% menjadi 40,62\% setelah diberi tindakan pada siklus 1 . Perhitungan ketuntasan belajar siswa secara klasikal ini digunakan untuk mengetahui besarnya prosentase siswa yang telah memenuhi kriteria tuntas belajar untuk satu kelas. Dari hasil analisis penilaian hasil belajar siswa di siklus 1, siswa yang belum mencapai ketuntasan belajar sebanyak 19 (Sembilan belas) siswa, dengan rata-rata prosentase ketuntasan belajar sebesar 40,62\%. Hasil belajar tersebut belum memenuhi indikator keberhasilan ketuntasan belajar klasikal, yaitu sekurang-kurangnya 85\% dari keseluruhan siswa yang ada di kelas tersebut memperoleh nilai minimal 70.

Pada siklus 2 pembelajaran kooperatif dengan permainan puzzle dalam pembelajaran kooperatif diperoleh nilai rata-rata siswa 71 dengan persentase ketuntasan belajar secara klasikal adalah $71,87 \%$. Sesuai tabel tersebut di atas, terlihat adanya kenaikan cukup signifikan dalam hal ketuntasan belajar klasikal siswa, yaitu dari sebelum dilakukan tindakan sebesar 40,62\% menjadi 71,87\% setelah diberi tindakan pada siklus 2. Perhitungan ketuntasan belajar siswa secara klasikal ini digunakan untuk mengetahui besarnya prosentase siswa yang telah memenuhi kriteria tuntas belajar untuk satu kelas. Dari hasil analisis penilaian hasil belajar siswa siklus 2, siswa yang belum mencapai ketuntasan belajar sebanyak 9 (Sembilan) siswa, dengan rata-rata prosentase ketuntasan belajar sebesar 71,87\%. Hasil belajar tersebut belum memenuhi indikator keberhasilan ketuntasan belajar klasikal, yaitu sekurang-kurangnya 85\% dari keseluruhan siswa yang ada di kelas tersebut.

Pada siklus 3 pembelajaran kooperatif dengan permainan puzzle dalam pembelajaran kooperatif diperoleh nilai rata-rata siswa 75 dengan persentase ketuntasan belajar secara klasikal adalah 78,12\%. Perbandingan hasil belajar sebelum dan sesudah siklus 3 dapat dilihat sebagai berikut. Sesuai tabel tersebut di atas, terlihat adanya kenaikan cukup signifikan dalam hal ketuntasan belajar klasikal siswa, yaitu dari siklus 2 sebesar $71,87 \%$ menjadi $78,12 \%$ setelah diberi tindakan pada siklus 3. Perhitungan ketuntasan belajar siswa secara klasikal ini digunakan untuk mengetahui besarnya prosentase siswa yang telah memenuhi kriteria tuntas belajar untuk satu kelas. Dari hasil analisis penilaian hasil belajar siswa siklus 3, siswa yang belum mencapai ketuntasan belajar sebanyak 7 (tiga) siswa, dengan rata-rata prosentase ketuntasan belajar sebesar $78,12 \%$. Hasil belajar tersebut masih belum memenuhi indikator 
keberhasilan ketuntasan belajar klasikal, yaitu sekurang-kurangnya 85\% dari keseluruhan siswa yang ada di kelas tersebut berikut,

Rekap data hasil belajar dari tabel satu dapat diperjelas dengan mengamati grafik

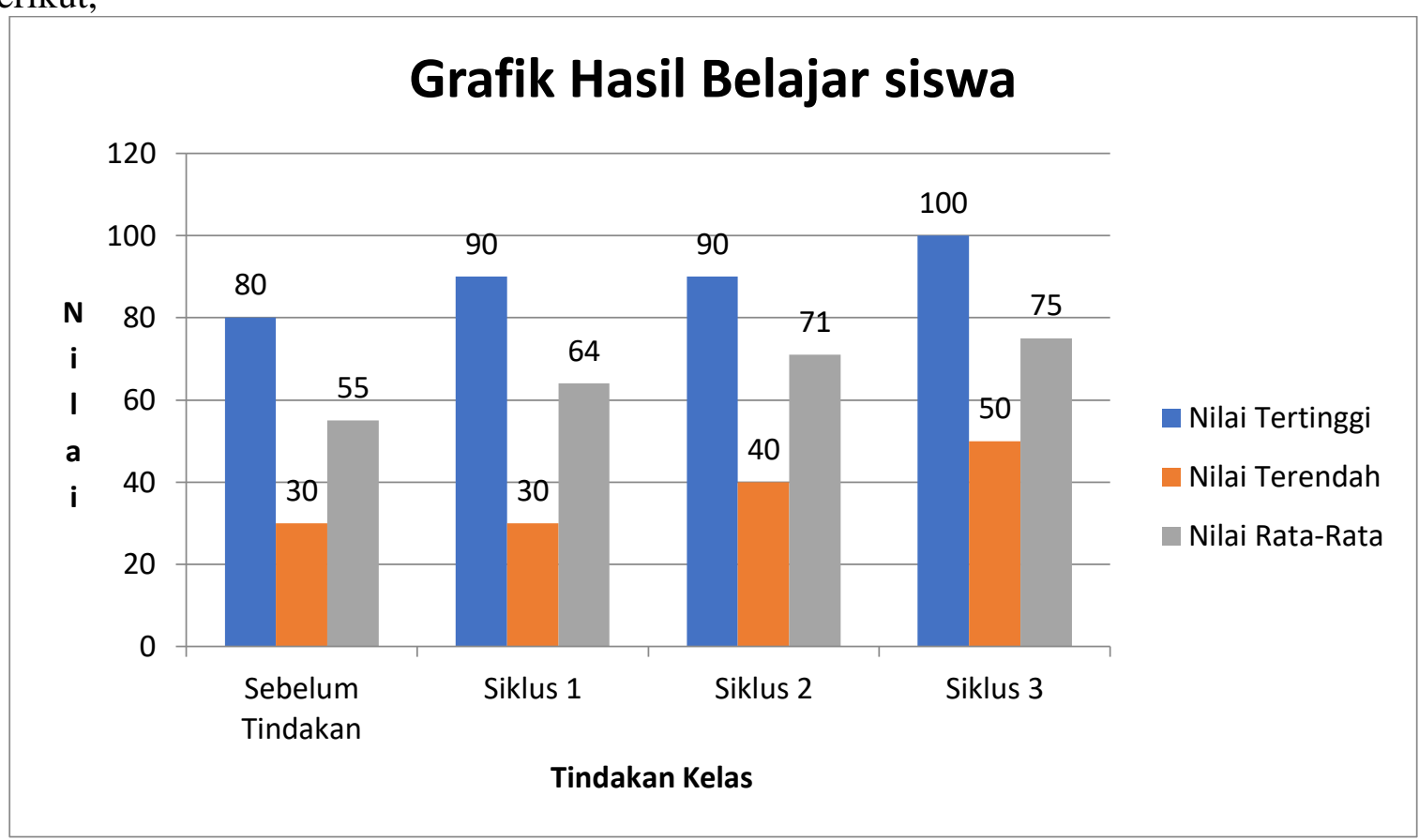

\section{Gambar 1. Grafik Hasil Belajar IPA}

Berdasarkan grafik diatas tampak dengan jelas bahwa seluruh nilai hasil belajar siswa mengalami peningkatan. Baik dari capaian nilai tertinggi, nilai terendah maupun nilai rata-rata yang diperoleh siswa. Diantara ketiga capaian nilai yang diperoleh siswa yang mengalami kenaikan nilai secara konsisten pada tiap siklusnya adalah capaian rata-rata nilai siswa. Hal ini yang menyebabkan ketuntasan hasil belajar klasikal juga meningkat. Untuk membuktikan hal tersebut dapat diamati gambar grafik berikut.

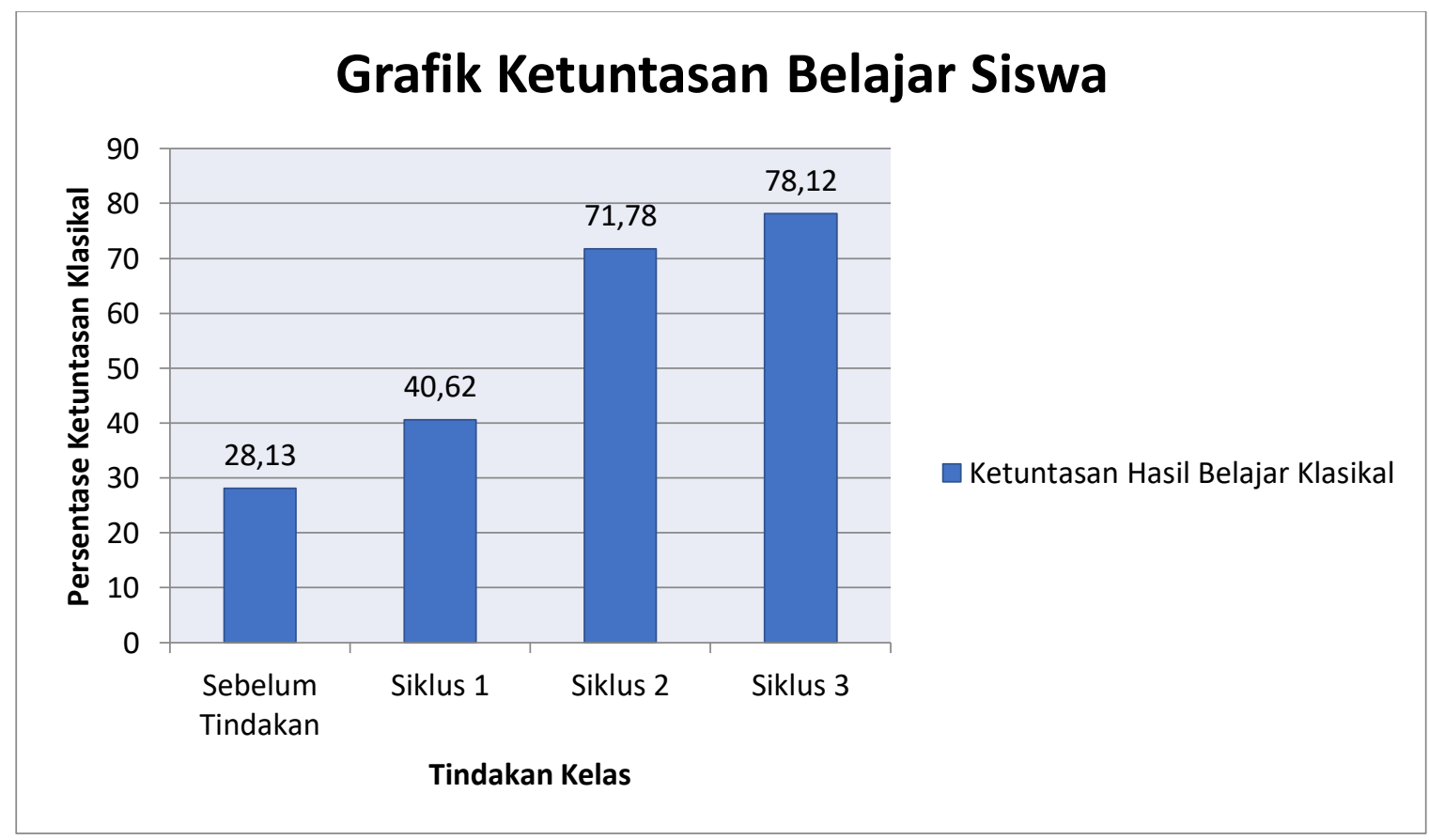

Gambar 2. Grafik Ketuntasan Hasil Belajar Secara Klasikal 
Dari grafik ketuntasan belajar klasikal di atas tampak bahwa tindakan yang diberikan pada tiap siklusnya berdampak pada peningkatan hasil belajar siswa. Walaupun jika dilihat dari gambar 2 terlihat bahwa nilai terendah dari sebelum tindakan dan pada siklus 1 masih sama akan tetapi capaian nilai tuntas ke atas (mencapai KKM ke atas) yang diperoleh oleh siswa jumlahnya bertambah, begitu juga dengan nilai yang diperoleh pada siklus 2 dan siklus 3 .

Data hasil observasi aktivitas siswa dengan menggunakan pembelajaran kooperatif dengan permainan Puzzle pada materi organisasi mahluk hidup di siklus 1 diperoleh hasil sebagai berikut,

Tabel 2 Hasil Observasi Aktivitas Siswa Siklus 1

\begin{tabular}{|c|c|c|c|c|}
\hline \multirow{2}{*}{ No } & \multirow{2}{*}{ Indikator } & \multicolumn{3}{|c|}{ Kriteria } \\
\hline & & Siklus 1 & Siklus 2 & Siklus 3 \\
\hline 1 & $\begin{array}{l}\text { Membaca dengan aktif (misal } \\
\text { dengan pen di tangan untuk } \\
\text { menggaris bawahi atau membuat } \\
\text { catatan kecil atau tanda-tanda } \\
\text { tertentu pada teks }\end{array}$ & Baik & Baik & Baik \\
\hline 2 & $\begin{array}{l}\text { Mendengarkan dengan aktif } \\
\text { (menunjukkan respon, misal } \\
\text { tersenyum atau tertawa saat } \\
\text { mendengar hal-hal lucu yang } \\
\text { disampaikan, terkagum-kagum bila } \\
\text { mendengar sesuatu yang } \\
\text { menakjubkan, dsb) }\end{array}$ & Cukup & Baik & Baik \\
\hline 3 & Berlatih & Baik & Baik & Sangat Baik \\
\hline 4 & Berpikir kritis & Kurang & Cukup & Baik \\
\hline 5 & Mengemukakan pendapat & Cukup & Cukup & Baik \\
\hline 6 & Berdiskusi & Baik & Baik & Sangat Baik \\
\hline 7 & $\begin{array}{l}\text { Memperbaiki kesalahan atau } \\
\text { kekurangan dalam proses } \\
\text { pembelajaran }\end{array}$ & Cukup & Baik & Baik \\
\hline 8 & $\begin{array}{l}\text { Menyimpulkan materi pembelajaran } \\
\text { dengan kata-katanya sendir }\end{array}$ & Cukup & Baik & Baik \\
\hline \multicolumn{2}{|r|}{ Jumlah Skor } & 26 & 30 & 34 \\
\hline \multicolumn{2}{|c|}{ Sko Maksimal } & 40 & 40 & 40 \\
\hline \multicolumn{2}{|c|}{$\%$ Skor } & 65 & 75 & 85 \\
\hline
\end{tabular}

Secara keseluruhan aktivitas siswa dalam pembelajaran pada siklus 1 dalam kriteria baik dengan jumlah skor 26 dan persentase skor $65 \%$. Meskipun demikian, masih ada beberapa kekurangan yang harus diperbaiki dalam siklus berikutnya. Berdasarkan data hasil penelitian pada siklus 1, menunjukkan bahwa siswa belum mampu menyesuaikan pada proses pembelajaran kooperatif dengan permainan puzzle itu masih dirasakan sebagai hal yang baru. Hal tersebut dapat dilihat dari beberapa temuan sebagai berikut. (a) Masih banyak siswa yang belum mampu memasang gambar puzzle dengan benar dan (b) siswa masih kurang optimal dalam pembelajaran, sehingga pada saat menyajikan hasil kerja kelompok dan kegiatan diskusi berlangsung, masih banyak siswa yang kurang aktif.

Secara keseluruhan aktivitas siswa dalam pembelajaran pada siklus 2 dalam kriteria baik dengan jumlah skor 30 dan persentase skor $75 \%$. Meskipun demikian, masih ada beberapa kekurangan yang harus diperbaiki dalam siklus berikutnya. Berdasarkan data hasil penelitian pada siklus 2, menunjukkan bahwa ada beberapa siswa belum mampu menyesuaikan pada proses pembelajaran kooperatif dengan permainan puzzle ini, karena metode pembelajaran itu 
masih dirasakan sebagai hal yang baru. Secara keseluruhan aktivitas siswa dalam pembelajaran pada siklus I dalam kriteria baik dengan jumlah skor 30 dan persentase skor $75 \%$. Meskipun demikian, masih ada beberapa kekurangan yang harus diperbaiki dalam siklus berikutnya. Berdasarkan data hasil penelitian pada siklus 2, menunjukkan bahwa ada beberapa siswa masih belum mampu menyesuaikan pada proses pembelajaran kooperatif dengan permainan puzzle ini, karena metode pembelajaran itu masih dirasakan sebagai hal yang baru

Secara keseluruhan aktivitas siswa dalam pembelajaran pada siklus 3 dalam kriteria baik dengan jumlah skor 34 dan persentase skor $85 \%$.. Berdasarkan data hasil penelitian pada siklus 3 , menunjukkan bahwa masih ada siswa belum mampu menyesuaikan pada proses pembelajaran kooperatif dengan permainan puzzle ini. Hal tersebut dapat dilihat dari beberapa temuan sebagai berikut: Masih ada siswa yang belum mampu memasang gambar puzzle dengan benar dikarenakan rendahnya kemampuan membaca dan mengingat konteks materi pelajaran. Di siklus 3 hasil belajar maupun aktivitas siswa semakin membaik dari siklus-siklus sebelumnya.

Hasil penelitian disiklus 1,2, dan 3 yang menunjukan adanya perbaikan dari aktivitas dan hasil belajar siswa kelas VII SMP Negeri 4 Pringsewu Tahun Pelajaran 2018/2019. Dari hasil penelitian diperoleh data hasil peneliatian dari katagori cukup baik menjadi baik dan untuk hasil rata-rata hasil belajar siswa dari sebelum tindakan kelas hingga siklus 3 diperoleh data yang meningkat dari 55 menjadi 75 dikuti ketuntasan klasikal yang juga semakin membaik dari ketercapaian $28,13 \%$ menjdi $78,12 \%$. Walaupun data tersebut belum menunjukan ketuntasan klasikal yang kita harapkan akan tetapi hal ini sudah menunjukan bahwa pembelajaran kooperatif dengan permainan puzzle dapat meningkatkan aktivitas dan hasil belajar siswa kelas VII di SMP Negeri 4 Pringsewu pada materi Organisasi mahluk hidup.

Peningkatan aktivitas belajar siswa dapat dilihat pada proses pembelajaran kooperatif dengan permainan puzzle. Siswa dengan karaktristik suka bermain akan memanfaatkan waktu yang diberikan guru dengan bermain kartu puzzle dalam memahami materi organisasi mahluk hidup dengan melakukan aktivitas membaca, diskusi, bertanya, melakukan latihan, menyimpulkan materi pelajaran dan mendengar dengan baik. Walaupun pada siklus 1 masih banyak siswa yang mengalami kesulitan menggunakan kartu puzzle karena ketidakpernahan menggunakan permainan puzzle ini akan tetapi pada siklus 2 dan siklus 3 kendala yang dihadapi siswa sudah terurai dengan baik sehingga semakin sedikit siswa yang tidak bisa menggunakan kartu puzzle tersebut.

Semakin banyaknya siswa yang dapat menggunakan kartu puzzle secara langsung menunjukan semakin baik aktivitas belajar siswa dikelas dalam memahami materi yang disampaikan guru sehingga menghasilkan peningkatan hasil belajar siswa di setiap siklusnya. Hal ini sesuai dengan pendapat Poerwadarminta (2003:23), aktivitas belajar adalah kegiatankegiatan siswa yang menunjang keberhasilan belajar. Berdasarkan pendapat tersebut dapat dikatakan bahwa jika aktivitasnya baik maka hasil belajarnya pun akan baik, Aktivitas belajar merupakan serangkaian kegiatan pembelajaran yang dilakukan siswa selama proses pembelajaran. Dengan melakukan berbagai aktivitas dalam kegiatan pembelajaran diharapkan siswa dapat membangun pengetahuannya sendiri tentang konsep-konsep dengan bantuan guru sebagai fasilitator. Sebagai fasilitator, guru harus jeli mengunakan strategi pembelajaran dalam hal ini menggunakan pembelajaran kooperatif dengan permainan puzzle. Pembelajaran kooperatif juga dapat meningkatkan aktivitas belajar siswa, hal ini sesuai dengan pendapat Sunal dan Hans dalam Isjoni (2009:15) mengemukakan bahwa pembelajaran kooperatif merupakan suatu cara pendekatan atau serangkaian strategi yang khusus dirancang untuk memberi dorongan kepada siswa agar bekerja sama selama proses pembelajaran (aktivitas belajar). Selanjutnya Stahl dalam Isjoni (2009: 15) menyatakan pembelajarankooperatif dapat meningkatkan belajar siswa lebih baik dan meningkatkan sikap saling tolong-menolong dalam perilaku sosial. Dari pendapat para ahli ternyata dapat dibuktikan bahwa pembelajaran kooperatif dengan permainan puzzle dapat meningkatkan aktivitas dan hasil belajar siswa. 
Tiga siklus dilakukan dalam penelitian tindakan kelas ini masih belum mencapai ketuntasan klasikal 85\% hal ini disebabkan entake siswa yang memang tidak dapat di rubah dalam waktu singkat.Siswa yang lambat untuk dirubah mungkin butuh penelitian khusus untuk memberikan tindakan yang khusus juga terhadap anak-anak tersebut.

\section{KESIMPULAN}

Berdasarkan hasil penelitian tentang upaya meningkatkan aktivitas dan hasil belajar materi organisasi mahluk hidup pada siswa kelas VII SMP Negeri 4 Pringsewu kabupaten Pringsewu semester 2 tahun pelajaran 2018/2019 pada mata pelajaran IPA Terpadu dengan model pembelajaran kooperatif melalui permainan puzzle dapat disimpulkan sebagai berikut:

(1) Penerapan pembelajaran kooperatif dengan permaian puzzle pada materi organisasi mahluk hidup pada siklus 1 ketuntasan belajar klasikal siswa sebesar 40,28\% dengan nilai rata-rata 64 . Pada siklus 2, ketuntasan belajar klasikal siswa sebesar $71.87 \%$ dengan nilai rata-rata 71 dan pada siklus 3 diperoleh ketuntsan klasikal sebesar 78,86\% dengan rata-rata 75 . Model pembelajaran kooperatif dengan permainan puzzle lebih efektif untuk meningkatkan hasil belajar siswa kelas VII SMP Negeri 4 Pringsewu pada mata pelajaran IPA Terpadu materi organisasi mahluk hidup. (2) Aktivitas siswa dalam pembelajaran dengan model pembelajaran kooperatif dengan permainan puzzle pada siklus 1 dalam kategori cukup baik. Pada siklus 2 diperoleh skor aktivitas siswa yang meningkat baik, dan pada siklus ke 3 aktivitas siswa sudah lebih baik dari siklus sebelumnya. (3) Langkah yang dilakukan untuk meningkatkan hasil belajar IPA terpadu materi organisasi mahluk hidup melalui penerapan model pembelajaran kooperatif dengan permainan puzzle merupakan pembelajaran yang dilakukan sambil bermaian. Kegiatan permainan puzzle ini disertai dengan kegiatan diskusi baik di dalam kelompok atau pun antar kelompok dan pemahaman dan pendalaman materi dilakukan ketika siswa belajar bersama dalam kelompok serta menambah antusias belajar siswa di kelas.

\section{DAFTAR PUSTAKA}

Agus, Suprijono. (2010). Cooperative Learning. Yogyakarta. Pustaka Media

Arikunto, Suharsimi. (2006). Penelitian Tindakan Kelas. Jakarta : Bumi Aksara.

BSNP. (2006). Permendiknas RI No. 22 Tahun 2006 tentang Standar Isi untuk Satuan Pendidikan Dasar dan Menengah. Jakarta.

Dimyanti dan Mudjiono. (2006). Belajar dan Pembelajaran. Jakarta: Rineka Cipta.

Etik. (2017). Upaya Meningkatkan Proses Dan Hasil Belajar Matematika Dengan

Menggunakan Model Discovery Learning. Jurnalmitra pendidikan. 32-33

Hamalik, Oemar. 2007. Proses Belajar Mengajar. Jakarta: PT. Bumi Aksara.

Hamalik, Oemar. 2010. Proses Belajar Mengajar. Jakarta : Bumi Aksara

Isjoni, (2010). Cooperative Learning Efektivitas Pembelajaran Kelompok. Bandung: Alfabeta. Isjoni. (2009). Cooperative Learning Efektivitas Pembelajaran Kelompok. Bandung: Alfabeta

Kemampuan Berpikir Kritis Dan Penalaran Logis Matematis Siswa. Jurnal Matematika dan Pendidikan Matimatika, 84-85

La Nani, Karman. (2016). Pengembangan Pembelajaran Kooperatif Dalam Mengkonstruksi

Lailatul M, Dzulkifli Efendi dan Titi Teri Purwati. (2013). Penerapan Model Pembelajaran

Kooperatif Tipe Tpsuntuk Meningkatkan Aktivitas Belajar Siswa Pada pokok Bahasan Matriks. Jurnal Pendidikan Matematika STKIP Sidoharjo. 118

Mulyasa.(2008). Menjadi Guru Profesional Menciptakan Pembelajaran Kreatif dan Menyenangkan. Bandung : PT. Remaja Rosdakarya.

Nisak, Raisatun. (2011). Lebih Dari 50 Game Kreatif Untuk Aktivitas Belajar Mengajar. Yogjakarta: Diva Press.

Poerwadarminta. W.J.S. (2003). Kamus Umum Bahasa Indonesia. Jakarta: Balai Pustaka Trianto. (2010). Model Pembelajaran Terpadu Konsep, Strategi, dan Implementasinya dalam KTSP. Jakarta: Bumi Aksara. 